Article

\title{
Antioxidant, Antimicrobial, Antidiabetic and Cytotoxic Activity of Crocus sativus L. Petals
}

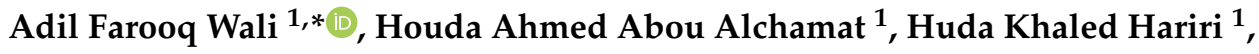 \\ Bushra Khaled Hariri ${ }^{1}$, Godfred A. Menezes ${ }^{2}$, Uzma Zehra ${ }^{3}$, Muneeb U. Rehman ${ }^{4}$ (D) \\ and Parvaiz Ahmad 5,*(iD) \\ 1 Department of Pharmaceutical Chemistry, RAKCOPS, RAK Medical and Health Sciences University, \\ 11172 Ras Al Khaimah, UAE; Houda.16903016@rakmhsu.ac.ae (H.A.A.A.); \\ Huda.16903043@rakmhsu.ac.ae (H.K.H.); Boshra.16903044@rakmhsu.ac.ae (B.K.H.) \\ 2 Department of Microbiology, RAKCOM, RAK Medical and Health Sciences University, \\ 11172 Ras Al Khaimah, UAE; godfred@rakmhsu.ac.ae \\ 3 Invasion Biology, Department of Botany, School of Biological Sciences, University of Kashmir, \\ Srinagar, J\&K 190006, India; mir_zehra@yahoo.com \\ 4 Department of Clinical Pharmacy, College of Pharmacy, King Saud University, 11451 Riyadh, Saudi Arabia; \\ muneebjh@gmail.com \\ 5 Department of Botany and Microbiology, College of Science, King Saud University, \\ 11451 Riyadh, Saudi Arabia \\ * Correspondence: adilfarooq25@gmail.com (A.F.W.); parvaizbot@yahoo.com (P.A.)
}

Received: 16 January 2020; Accepted: 13 February 2020; Published: 23 February 2020

check for updates

\begin{abstract}
The purpose of this research is to examine in vitro antioxidant, antimicrobial, antidiabetic and cytotoxic efficacy of different extracts of Crocus sativus L. petals. Antioxidant activity of extracts was assessed by DPPH and ABTS (2,2'-azino-bis (3-ethylbenzothiazoline-6-sulfonic acid) assay. Among all extracts, ethanol (SPE) had the maximum radical scavenging activity with $\mathrm{IC}_{50}$ values $86.63 \pm 7.53 \mu \mathrm{g} / \mathrm{mL}$. The antimicrobial activity was determined by the evaluation of the minimum inhibitory concentration using the agar well plate procedure. The most effective extract was SPE with a minimum inhibitory concentration varying between $500 \mu \mathrm{g} / \mathrm{mL}, 250 \mu \mathrm{g} / \mathrm{mL}, 125 \mu \mathrm{g} / \mathrm{mL}, 62.5 \mu \mathrm{g} / \mathrm{mL}$, $31.25 \mu \mathrm{g} / \mathrm{mL}, 15.63 \mu \mathrm{g} / \mathrm{mL}$. Cytotoxic activity was tested against MDA-MB-231 cell lines using the MTT method whereas, antidiabetic activity was evaluated using an alpha-glucosidase inhibition assay. All extracts were found to have significant antidiabetic activity.
\end{abstract}

Keywords: anti-diabetic; Crocus sativus L. petals; ABTS assay; cytotoxic; polyphenols; FTIR

\section{Introduction}

According to the World Health Organization, infectious diseases are one of the major threats to human beings [1]. The prevalence of species susceptible to various antimicrobial agents has increased, resulting in increased morbidity, mortality and total treatment costs [2]. The overuse of antibiotics contributes to the rapid development of multidrug-resistant pathogens [3]. The continued rise in the magnitude of multidrug resistance to traditional antibiotics is a biggest concern of researchers and practitioners globally and it has become a worldwide problem in recent decades [4]. The increasing number of incidents of infectious diseases associated with the emergence of antimicrobial resistance helps in the discovery of new antimicrobial agents [5].

Natural products have a significant role in the health care sector and have been used for the prevention of several infectious diseases since ancient times [6]. Such products including medicinal plant extract, are important source for the development of novel disease therapies [7,8]. Over recent decades, the use of medicinal plants has become increasingly integral to the world's primary health 
care needs. Medicinal plants are the cornerstone of traditional complementary and alternative medical practice, as many current drugs and their derivatives are isolated from these plants [9]. Plants are known as being the most effective antimicrobial agents due to the presence of polyphenolic compounds [10]. Plants may contain a number of biologically active compounds, and all these compounds have the potential for effective therapeutic effect [11,12].

Crocus sativus L. (Saffron) (family Iridaceae) is often used as a spice in various parts of the world and as a therapeutic agent for a range of diseases [13]. The name of saffron was derived from the Arabic word "zafaran", meaning yellow [14]. Literature survey revealed that more than 100 bioactive compounds has be isolated from saffron stigma mainly flavonoids [15], terpenoids [16], anthraquinones [17]. Saffron has been used in folk medicines to treat multiple conditions, including cough, gastrointestinal, menstrual irregularities and cardiovascular ailments [18]. Recent pharmacological analysis of saffron stigma and petals showed a broad range of biological activities like antioxidant [19], anticancer [20], neuroprotective [21], antidiabetic [22], aphrodisiac [23], hypolipidemic [24], anti-inflammatory [25], antimicrobial activities [26], etc.

The objective of this work was to evaluate the antioxidant, antimicrobial, antidiabetic and cytotoxic effects of $C$. sativus L. petals using various screening tests.

\section{Materials}

Petals of the C. sativus L were collected from Pampore $\left(34.02^{\circ} \mathrm{N} 74.93^{\circ} \mathrm{E}\right.$.), Kashmir, J\&K, India. The petals were shade dried for a week and the moisture content evaluated by using an oven. The air-dried petals were coarsely powdered with a grinder (Moulinex-Mc300). The powder was stored in an air-tight container and placed at dry place.

\subsection{Preparation of Extracts}

About $10 \mathrm{~g}$ of coarsely powdered C. sativus L petals were filled in the cellulose thimble and transferred to a soxhlet apparatus. The apparatus was filled with $200 \mathrm{~mL}$ of solvent and reflux it till color of the solvents fades using a heating mantel. In the current study three different solvents were used for extraction based on the polarity of the solvents. Starting from the least polar solvent, i.e., hexane (SPH) followed by dichloromethane (SPD) and lastly by ethanol (SPE). After completion of each extraction cycle, all extracts were filtered and evaporated at $50^{\circ} \mathrm{C}$ at 100 bar using vacuo (Buchi Rotavapor $\left.{ }^{\circledR} \mathrm{R}-210\right)$. All the extracts were stored in the desiccator for further testing.

\subsection{Extraction Yield of Each Extract of C. sativus L Petals}

The extraction yield of each extract obtained from C. sativus L petals was calculated using the following formula:

$$
\text { Extraction yield }=\mathrm{Ac} / \mathrm{Ar} * 100
$$

where, $\mathrm{Ac}=$ Weight of each extract in grams, $\mathrm{Ar}=$ Weight of the $C$. sativus L. petals in grams

\subsection{Estimation of Total Phenolic Content (TPC) and Total Flavonoid Content (TFC)}

Folin-Ciocalteu's assay and colorimetric method were used to evaluate the total phenolic content [27] and total flavonoid content [28] of the C. sativus $\mathrm{L}$ in each extract.

\subsection{In-vitro Antioxidant Activity}

The antioxidant activity of all C. sativus $\mathrm{L}$ extracts were determined by DPPH (2,2-diphenyl-1-picrylhydrazyl) [29] and ABTS (2,2'-azino-bis (3-ethylbenzothiazoline-6-sulfonic acid) [30] assays.

DPPH assay: Aliquots of $300 \mu \mathrm{L}$ with different concentrations of SPH, SPD, SPE and BHA (positive control) were mixed individually with a solution of $0.2 \mathrm{mmol} / \mathrm{L} \mathrm{DPPH} \mathrm{in} \mathrm{methanol} \mathrm{(negative} \mathrm{control),} \mathrm{the}$ mixture was vigorously mixed together and kept to incubate at room temperature for $20 \mathrm{~min}$ in the dark. 
The absorbance values were documented at $517 \mathrm{~nm}$ using a UV-1800 UV-Spectrophotometer (Shimadzu Corp. Japan). The absorbance measured for the control solution was $0.932 \pm 0.10$. The inhibition percentage of DPPH discoloration was measured using Equation (2).

$$
\% \text { inhibition }=[\mathrm{Ax}-\mathrm{Az} / \mathrm{Ax} * 100]
$$

where $\mathrm{Ax}$ is the absorbance of control and $\mathrm{Az}$ is the absorbance of the extract/reference sample.

All the samples were investigated in triplicate.

ABTS assay: The ABTS radical cation $\left(\mathrm{ABTS}^{\bullet+}\right.$ ) was generated by the reaction of $7 \mathrm{mM}$ ABTS (Solution " $\mathrm{A}$ ") and $2.4 \mathrm{mM}$ potassium persulfate (Solution " $\mathrm{B}$ "). The working solution was prepared by mixing solution " $\mathrm{A}$ " and " $\mathrm{B}$ " in a 1:1 ratio and allowing them to stand in a dark place for $24 \mathrm{~h}$ at $37^{\circ} \mathrm{C}$. After $24 \mathrm{~h}$, the negative control was prepared by mixing $1 \mathrm{~mL}$ of ABTS+ solution with $0.50 \mathrm{~mL}$ of double distilled water to achieve an absorbance of above $0.700 \pm 0.07$ at $734 \mathrm{~nm}$ using a UV-visible spectrophotometer while BHA has been used as a positive control. Percentage results of the scavenging activity were calculated as a \% inhibition by using Equation (2) above.

$\mathrm{IC}_{50}$ values (concentration or $\log$ concentration on the $x$-axis and their relative percentage inhibition on the $y$-axis) were obtained from experimental DPPH and ABTS assays.

\subsection{Fourier Transform Infrared Spectrometry (FTIR) Analysis of C. sativus L. Petals Extracts}

The FTIR analyses of all extracts were carried out on a Cary 630 FTIR Spectrophotometer (Agilent Technologies, USA) equipped with MicroLab software. The spectra have been documented at wavelengths between 4000 and $600 \mathrm{~cm}^{-1}$, with a resolution of $8 \mathrm{~cm}^{-1}$. The spectra collected for the extracts were analyzed in a graph for the characteristics of the infrared absorption frequencies of the functional groups.

\subsection{Antimicrobial Activity}

All three extracts of C. sativus L. petals were evaluated against Gram-positive bacteria Staphylococcus aureus (ATCC 25923), Gram-negative bacteria Pseudomonas aeruginosa (ATCC 27853), and Escherichia coli (ATCC 25922), and the fungi strain Candida albicans (NCPF-3179). All the procedure was performed according to National Committee for Clinical Laboratory Standards (NCCLS) using Muller Hinton agar as medium [31]. All the stock solutions of the extracts examined were prepared at a final concentration of $1 \%$ DMSO and measured at a concentration of $500 \mu \mathrm{g} / \mathrm{mL}, 250 \mu \mathrm{g} / \mathrm{mL}, 125 \mu \mathrm{g} / \mathrm{mL}$, $62.5 \mu \mathrm{g} / \mathrm{mL}, 31.25 \mu \mathrm{g} / \mathrm{mL}, 15.63 \mu \mathrm{g} / \mathrm{mL}$ for all extracts. Gentamicin and Fluconazole were used as reference drugs. The agar well plate was bored and each extract was introduced in to each well of different concentrations. After the incubation of the agar plates $\left(37^{\circ} \mathrm{C}\right.$ for $\left.24 \mathrm{~h}\right)$, the diameter of each zone of inhibition was measured. All tests have been performed in triplicate and the results obtained from the replicas were coincident.

\subsection{Antidiabetic Study}

The antidiabetic study was conducted using an alpha-glucosidase inhibition assay whereas Acarbose was used as the standard drug [32].

\subsection{Cytotoxic Activity}

The cytotoxicity activity was performed as described earlier by Yusra et al. [33]. The cells were seeded at a density of 5000 cells/well in 96-well plates. After $24 \mathrm{~h}$, the cells were incubated either alone or with a two-fold serial dilution of SPH, SPD and SPE starting at the highest concentration at $150 \mu \mathrm{g} / \mathrm{mL}$ at 24,48 and $72 \mathrm{~h}$ respectively. Then $20 \mu \mathrm{L}$ of MTT solution was transferred to each well and mixed. After $4 \mathrm{~h}$, the supernatants were separated and $100 \mu \mathrm{L}$ of DMSO was transferred for each well to dissolve the precipitate. Cell viability was calculated using a CellTiter-Glo Luminescent Cell 
Viability Assay (Promega Corporation, Madison, USA) based on ATP quantification, which indicates the presence of metabolically active cells.

The percentage of cell viability was calculated on the basis of the absorption ratio between the cell culture treated with SPH, SPD and SPE and the untreated control multiplied by 100 represents cell viability (percentage of control, percent). Cytotoxicity $\left(\mathrm{IC}_{50}\right)$ was quantified as the ratio of normal cells to cancer cells (MDA-MB-231).

\section{Statistical Analysis}

The data obtained were analyzed using Duncan's multiple range tests. The mean results are shown with their standard deviation. Statistical significance between treatments was described as $p<0.05$ for all tests.

\section{Results}

\subsection{Extraction Yield:}

The extraction yields of the C. sativus L petals were SPH 1.54\%, SPD $1.89 \%$ and SPE extracts $3.02 \%$ respectively. The maximum extraction yield was achieved using SPE and least was observed in SPH.

\subsection{Estimation of Total Phenolic Content (TPC) and Total Flavonoid Content (TFC)}

As the findings are shown in the Table 1. The maximum total phenolic and total flavonoid contents were reported in SPE $(83.98 \pm 1.30 \mathrm{mg}$ GAE$/ \mathrm{g}$ and $67.93 \pm 1.17 \mu \mathrm{g} \mathrm{QE} / \mathrm{g})$ followed by SPD $(59.23 \pm 1.25 \mathrm{mg} \mathrm{GAE} / \mathrm{g}$ and $49.84 \pm 1.15 \mu \mathrm{g} \mathrm{QE} / \mathrm{g})$ and least in SPH $(45.73 \pm 0.72 \mathrm{mg} \mathrm{GAE} / \mathrm{g}$ and $32.23 \pm 0.92 \mu \mathrm{g} \mathrm{QE} / \mathrm{g})$.

Table 1. Total phenolic and flavonoid content of different solvent extracts of C. sativus L petals.

\begin{tabular}{|c|c|c|c|c|c|c|}
\hline Assay & $\begin{array}{l}\text { Hexane } \\
(\mathrm{SPH})\end{array}$ & $\mathbf{R} 2$ & $\begin{array}{l}\text { Dichloromethane } \\
\text { (SPD) }\end{array}$ & $\mathbf{R} 2$ & $\begin{array}{l}\text { Ethanol } \\
\text { (SPE) }\end{array}$ & $\mathbf{R} 2$ \\
\hline $\begin{array}{l}\text { Total phenolic content } \\
\text { (mg GAE a /g of extract) }\end{array}$ & $45.73 \pm 0.72$ & 0.970 & $59.23 \pm 1.25$ & 0.989 & $\begin{array}{c}83.98 \pm \\
1.30\end{array}$ & 0.999 \\
\hline $\begin{array}{l}\text { Total flavonoids content } \\
\text { ( } \mu \mathrm{g} Q \mathrm{QE}^{\mathrm{b}} / \mathrm{g} \text { of extract) }\end{array}$ & $32.23 \pm 0.92$ & 0.999 & $49.84 \pm 1.15$ & 0.978 & $\begin{array}{c}67.93 \pm \\
1.17\end{array}$ & 0.988 \\
\hline
\end{tabular}

\subsection{In-Vitro Antioxidant Activity}

In the DPPH assay, the absorbance was found to decreases with the increase in concentration of all extracts. The least radical scavenging activity was found in SPH followed by SPD, while SPE displayed the strongest inhibition at the lowest $\mathrm{IC}_{50}$ values at a concentration of $25 \mu \mathrm{g} / \mathrm{mL}$ as shown in Table 2 . Whereas in ABTS assay, all the extracts exhibit strong scavenging activity, the sequence of the scavenging activities of all extracts were SPH $<$ SPD $<$ SPE at a concentration of $25 \mu \mathrm{g} / \mathrm{mL}$ as shown in Table 2 .

Table 2. Antioxidant activity of different solvent extracts of $C$. sativus L petals with DPPH and ABTS (2,2'-azino-bis (3-ethylbenzothiazoline-6-sulfonic acid) assays.

\begin{tabular}{|c|c|c|c|c|c|c|c|c|}
\hline Assay & $\begin{array}{c}\text { SPH } \\
\mathrm{IC}_{50}(\mu \mathrm{g} / \mathrm{mL})\end{array}$ & $\mathbf{R}^{2}$ & $\begin{array}{c}\text { SPD } \\
\mathrm{IC}_{50}(\mu \mathrm{g} / \mathrm{mL})\end{array}$ & $\mathbf{R}^{2}$ & $\begin{array}{c}\text { SPE } \\
\mathrm{IC}_{50}(\mu \mathrm{g} / \mathrm{mL})\end{array}$ & $\mathbf{R}^{2}$ & $\begin{array}{c}\text { BHA } \\
\mathrm{IC}_{50}(\mu \mathrm{g} / \mathrm{mL})\end{array}$ & $\mathbf{R}^{2}$ \\
\hline DPPH & $129.54 \pm 5.92$ & 0.952 & $102.01 \pm 4.21$ & 0.961 & $86.63 \pm 7.53$ & 0.953 & $70.32 \pm 4.19$ & 0.965 \\
\hline
\end{tabular}




\subsection{Identified Functional Groups in the Extracts}

Figure 1a represents the FTIR spectrum of SPH exhibited intense bands at $2917.581 \mathrm{~cm}^{-1}$ (C-H and $\mathrm{CH}_{2}$ vibration of aliphatic hydrocarbons), $2849.759 \mathrm{~cm}^{-1}$ (C-H stretching of aldehyde), $1707.975 \mathrm{~cm}^{-1}$ ( $\mathrm{C}=\mathrm{O}$ stretching), $1459 \mathrm{~cm}^{-1}$ (C-H bending), $1375.517 \mathrm{~cm}^{-1}$ (C-O stretching of the ester group), $1247.675 \mathrm{~cm}^{-1}$ (C-O stretching ester) and $1034.127 \mathrm{~cm}^{-1}$ (O-H deformation).
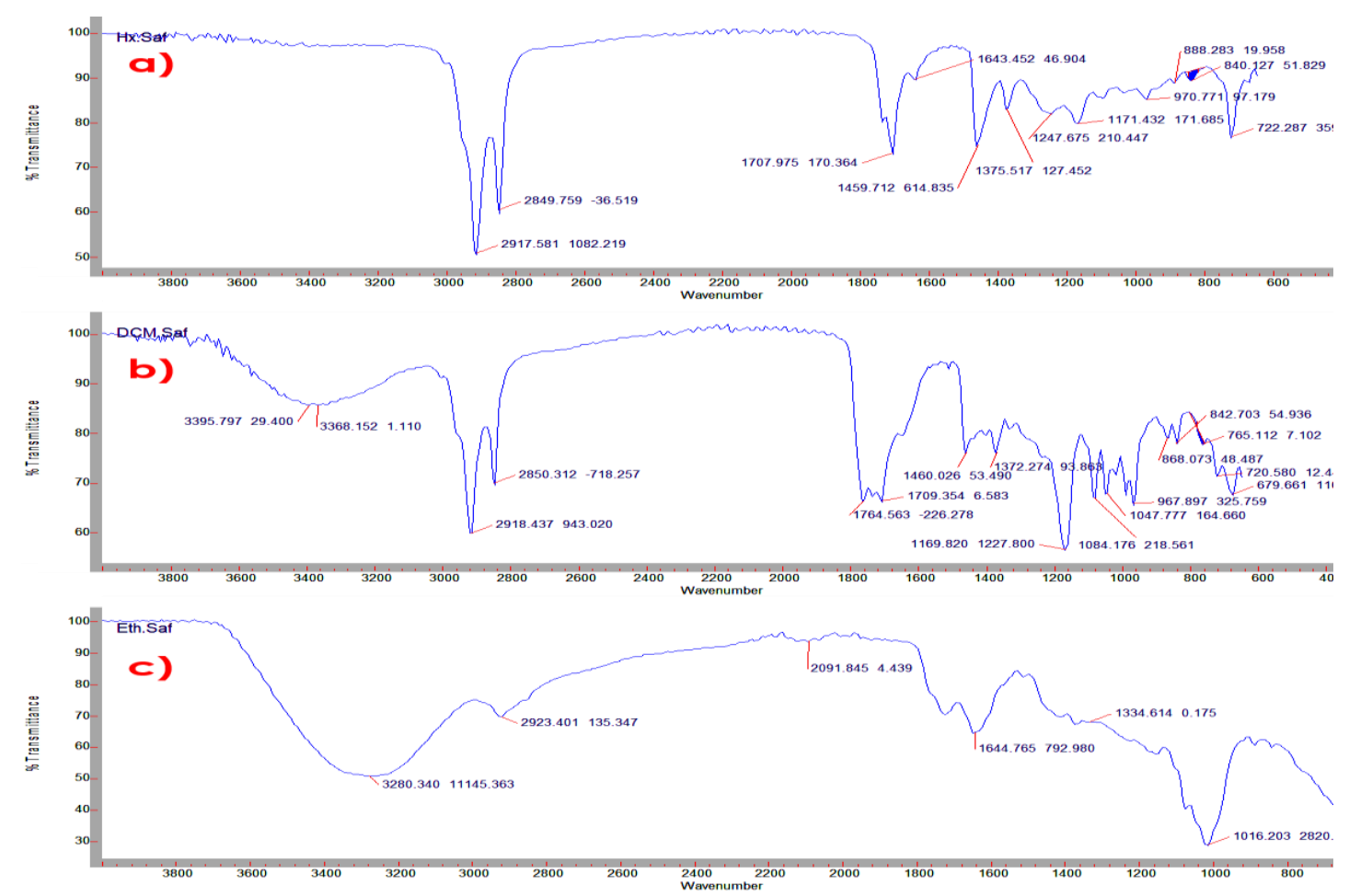

Figure 1. FTIR spectrum of C. sativus L petals extracts (a) SPH; (b) SPD and (c).

Figure $1 \mathrm{~b}$ the FTIR spectrum of SPD displayed broad bands at $3368.152 \mathrm{~cm}^{-1}$ confirms the presence of phenolic group, $2918.437 \mathrm{~cm}^{-1}$ (attributed to the $\mathrm{C}-\mathrm{H}$ and $\mathrm{CH}_{2}$ vibration of aliphatic hydrocarbons), $2850.312 \mathrm{~cm}^{-1}$ (C-H stretching of aldehyde), $1764.563 \mathrm{~cm}^{-1}$ ( $\mathrm{C}=\mathrm{O}$ stretching carboxylic acid), $1735.784 \mathrm{~cm}^{-1}$ ( $\mathrm{C}=\mathrm{O}$ stretching $\alpha, \beta$-unsaturated ester), $1169.820 \mathrm{~cm}^{-1}$ (C-O stretching tertiary alcohol) and $1084.176 \mathrm{~cm}^{-1}$ (C-O stretching primary alcohol).

Figure 1c the FTIR spectrum of SPE revealed broad bands at $3280.340 \mathrm{~cm}^{-1}$ confirms the presence of $\mathrm{OH}$ group, $2923.401 \mathrm{~cm}^{-1}$ (attributed to the $\mathrm{C}-\mathrm{H}$ and $\mathrm{CH}_{2}$ vibration of aliphatic hydrocarbons), $1700.52 \mathrm{~cm}^{-1}$ ( $\mathrm{C}=\mathrm{O}$ stretching carboxylic acid), $1625.53 \mathrm{~cm}^{-1}$ ( $\mathrm{C}=\mathrm{C}$ stretching $\alpha, \beta$-unsaturated ketone), $1334.614 \mathrm{~cm}^{-1}$ (C-O stretching aromatic ester) and $1222.321 \mathrm{~cm}^{-1}$ (C-O stretching ester).

\subsection{Antimicrobial Activity}

Antimicrobial activity of various extracts was investigated using agar well plate method against pathogens. A sequential dilution technique was used in this study the antimicrobial activity of extracts of C. sativus L. Findings suggest that SPH showed poor inhibitory effects on most of the bacteria and fungi examined, the minimum (or minimal) inhibitory concentration (MIC) values of the extracts against all the microorganisms tested were higher than $500 \mu \mathrm{g} / \mathrm{mL}$. However, strong antimicrobial activity was observed in SPE followed by SPD; the MIC values were lower than $15.63 \mu \mathrm{g} / \mathrm{mL}$ Table 3 . 
Table 3. Minimum (or minimal) inhibitory concentration (MIC) of extracts against various microbes.

\begin{tabular}{|c|c|c|c|c|c|}
\hline \multirow{3}{*}{ Extracts } & \multirow{3}{*}{ Conc. $\mu \mathrm{g} / \mathrm{mL}$} & \multicolumn{4}{|c|}{ Growth Inhibition Zone (mm) } \\
\hline & & \multirow{2}{*}{$\begin{array}{c}\text { Gram-Positive Bacteria } \\
\text { S. aureus }\end{array}$} & \multicolumn{2}{|c|}{ Gram-Negative Bacteria } & \multirow{2}{*}{$\begin{array}{c}\text { Fungi } \\
\text { C. albicans }\end{array}$} \\
\hline & & & P. aeruginosa & E. coli & \\
\hline \multirow{6}{*}{ SPH } & 500 & $10.6 \pm 0.90$ & $12.8 \pm 0.64$ & $5.7 \pm 0.49$ & $2.6 \pm 0.36$ \\
\hline & 250 & $8.9 \pm 0.67$ & $10.2 \pm-0.88$ & $1.8 \pm 0.93$ & $0 \pm 00$ \\
\hline & 125 & $6.1 \pm 0.83$ & $7.9 \pm 0.96$ & $0 \pm 00$ & $0 \pm 00$ \\
\hline & 62.5 & $3.7 \pm 0.70$ & $5.3 \pm 0.93$ & $0 \pm 00$ & $0 \pm 00$ \\
\hline & 31.25 & $0 \pm 00$ & $0 \pm 00$ & $0 \pm 00$ & $0 \pm 00$ \\
\hline & 15.63 & $0 \pm 00$ & $0 \pm 00$ & $0 \pm 00$ & $0 \pm 00$ \\
\hline \multirow{6}{*}{ SPD } & 500 & $15.4 \pm 0.54$ & $13.3 \pm 0.90$ & $6.5 \pm 0.69$ & $5.4 \pm 0.65$ \\
\hline & 250 & $13.8 \pm 0.98$ & $10.7 \pm 0.67$ & $3.0 \pm 0.35$ & $1.9 \pm 0.90$ \\
\hline & 125 & $10.5 \pm 0.77$ & $7.8 \pm 0.83$ & $0 \pm 00$ & $0 \pm 00$ \\
\hline & 62.5 & $8.9 \pm 0.34$ & $4.5 \pm 0.70$ & $0 \pm 00$ & $0 \pm 00$ \\
\hline & 31.25 & $5.3 \pm 0.80$ & $2.4 \pm 0.80$ & $0 \pm 00$ & $0 \pm 00$ \\
\hline & 15.63 & $0 \pm 00$ & $0 \pm 00$ & $0 \pm 00$ & $0 \pm 00$ \\
\hline \multirow{6}{*}{ SPE } & 500 & $18.2 \pm 0.98$ & $14.8 \pm 0.64$ & $9.7 \pm 0.90$ & $8.7 \pm 0.54$ \\
\hline & 250 & $16.5 \pm 0.53$ & $11.2 \pm-0.88$ & $7.4 \pm 0.64$ & $3.6 \pm 0.78$ \\
\hline & 125 & $12.2 \pm 0.89$ & $9.3 \pm 0.96$ & $2.0 \pm 0.90$ & $0 \pm 00$ \\
\hline & 62.5 & $11.5 \pm 0.43$ & $7.9 \pm 0.93$ & $0 \pm 00$ & $0 \pm 00$ \\
\hline & 31.25 & $10.8 \pm 0.48$ & $4.6 \pm 0.67$ & $0 \pm 00$ & $0 \pm 00$ \\
\hline & 15.63 & $8.3 \pm 0.77$ & $2.0 \pm 0.74$ & $0 \pm 00$ & $0 \pm 00$ \\
\hline Gentamicin & 10 & $22.19 \pm 0.55$ & $16.56 \pm 0.60$ & $12.43 \pm 0.89$ & - \\
\hline Fluconazole & 10 & - & - & - & $11.3 \pm 0.54$ \\
\hline
\end{tabular}

\subsection{Antidiabetic Study}

The $\alpha$-glucosidase inhibition of SPH, SPD and SPE of C. sativus L. petals are given in Figure 2. All the extracts revealed dose dependent $\alpha$-glucosidase inhibition with $\mathrm{IC}_{50}$ value $89.94 \pm 1.09,63.32 \pm 0.89$ and $31.83 \pm 1.39$ respectively. The $\mathrm{IC}_{50}$ value of Acarbose used as standard was found to be $19.83 \pm 0.89$.

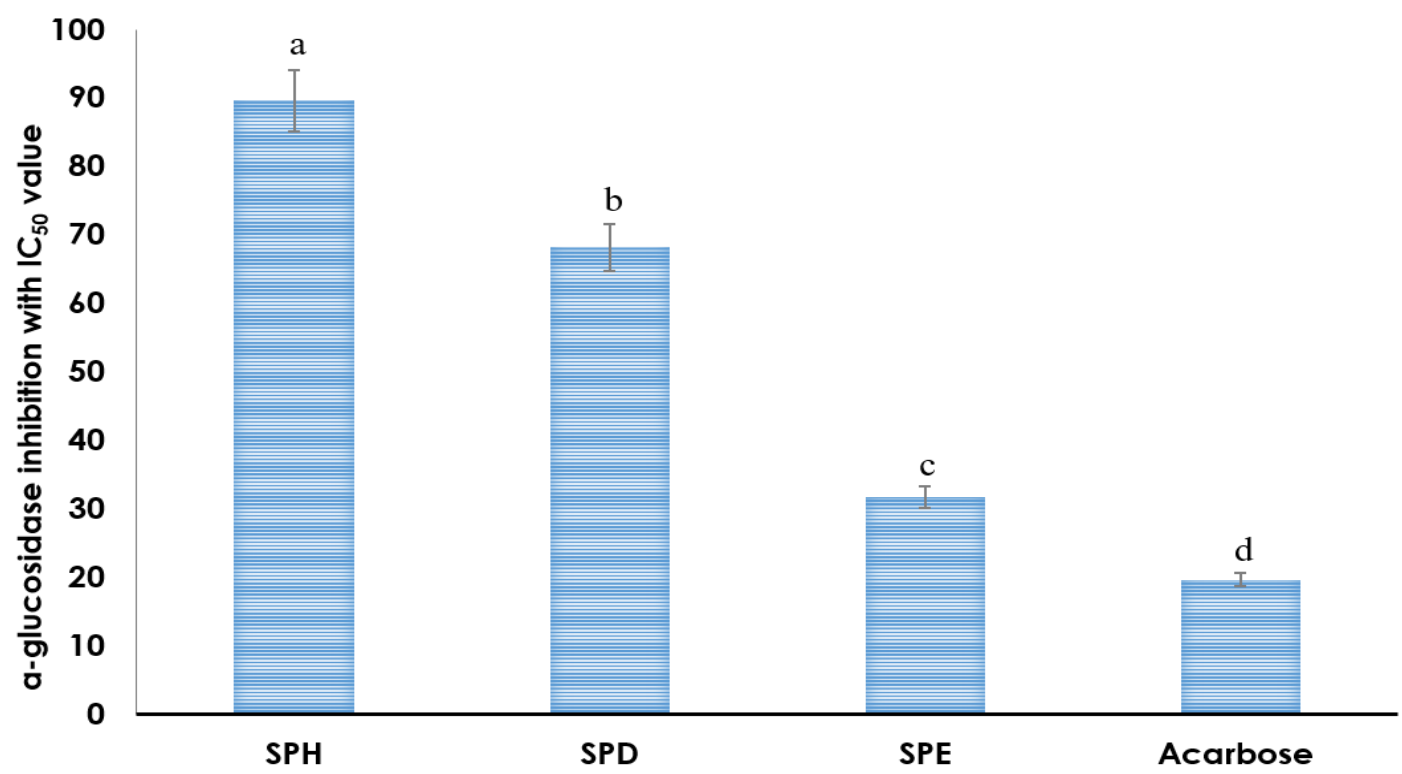

Figure 2. Bars demonstrate inhibition of $\alpha$-glucosidase by $5 \mathrm{mg} / \mathrm{mL}$ of crude $C$ sativus $\mathrm{L}$. petal extract in n-hexane, dichloromethane and ethanol. Acarbose $(1 \mathrm{mg} / \mathrm{mL})$ has been used as a standard drug. The bars are the mean \pm standard deviation of three observations. The bars of different alphabets are significantly different $(p<0.05)$. 


\subsection{Cytotoxic Activity}

The MTT cell viability assay was used to determine the cytotoxic activity of $C$. sativus L. petals extracts in MDA-MB-231 cell lines. In summary, an increase in dose-dependent inhibition rate was observed in extract-treated MDA-MB-231 cells. SPE had the highest inhibition of MDA-MB-231 cells, followed by SPD, and the lowest cytotoxicity was SPH $(p<0.05)$. The cytotoxic effects presented as $\mathrm{IC}_{50}$ values are shown in Table 4 . When the incubation time was $24 \mathrm{~h}$, SPE had the lowest $\mathrm{IC}_{50}$ value $(35.12 \pm 1.56 \mathrm{mg} / \mathrm{mL})$, followed by SPD $(71.29 \pm 0.87 \mathrm{mg} / \mathrm{mL})$ and SPH $110.56 \pm 1.67 \mathrm{mg} / \mathrm{mL})(p<0.05)$. Once the time was extended from $24 \mathrm{~h}$ to $48 \mathrm{~h}$, the inhibition rate for all extracts increased considerably, whereas the inhibition rate dropped marginally while the duration was increased again to $72 \mathrm{~h}$.

Table 4. In vitro growth inhibitory activity $\left(\mathrm{IC}_{50} \mathrm{mg} / \mathrm{mL}\right)$ of extracts of on MDA-MB-231 cell lines after $24 \mathrm{~h}, 48 \mathrm{~h}$ and $72 \mathrm{~h}$ of exposure.

\begin{tabular}{cccc}
\hline \multirow{2}{*}{ Extracts } & \multicolumn{3}{c}{ IC $_{\mathbf{5 0}}(\mathbf{m g} / \mathbf{m L})$} \\
\cline { 2 - 4 } & $\mathbf{2 4} \mathbf{~ h}$ & $\mathbf{4 8 ~ h}$ & $\mathbf{7 2 ~ h}$ \\
\hline SPH & $110.56 \pm 1.67^{\circledR}$ & $56.65 \pm 1.22^{\circledR}$ & $39.12 \pm 1.45^{\circledR}$ \\
SPD & $71.29 \pm 0.87^{*}$ & $40.43 \pm 1.02^{*}$ & $22.64 \pm 1.33^{*}$ \\
SPE & $35.12 \pm 1.56^{\#}$ & $19.35 \pm 1.54^{\#}$ & $12.98 \pm 2.53^{\#}$ \\
\hline
\end{tabular}

Mean values with different signs within the same column are statistically different $(\mathrm{n}=3$; \#< $0.05 ; @ p<0.01$, * $p<0.001$ vs. control, Duncan's multiple range tests).

\section{Discussion}

C. sativus L. is an important medicinal food plant which is widely cultivated in different parts of the globe for nutritional and economic purposes [34]. Literature survey revealed that different solvent extracts and isolated compounds of C. sativus L. stigma and corm have demonstrated various pharmacological effects. However, very less research has been done on the petals [35]. As a result, three different extracts were derived from the petals of $C$. sativus $L$ in the current study and they have all been evaluated for their biological activity, i.e., antioxidant, antidiabetic and antimicrobial activity.

Flavonoids are a category of natural compounds with different phenolic structures that are present in plants, are essential due to various their capacity to act as antioxidants [36,37]. Phenolic compounds are present widely in the kingdom of flora and are reported to be strong antioxidant [38]. Recent studies have shown that phenolic compositions have a possible protective role against oxidative ailments [39]. Phenolic compounds will transfer hydrogen to free radicals to avoid the lipid oxidation chain reaction at the initial stage. The capacity of phenolic compounds to scavenge radicals is due to the effects of their phenolic hydroxyl groups $[40,41]$. The total phenolic and flavonoid content observed in our study are compatible with Shoib et al., which showed that the C. sativus stigma possessed higher phenolic, flavonoid content and consequently higher antioxidant activity as compared to C. sativus petals [42].

Many earlier reports have showed significant correlation among total phenolic content and antioxidant activity. In this analysis, we used the DPPH and ABTS assay simply to verify that the extracts demonstrate antioxidant activity, and in future detailed studies. DPPH and ABTS assays have been the most specific tests used to assess the radical scavenging potential of different compounds because it has the ability to donate hydrogen to free radicals. The mechanism behind it's radical scavenging properties is due to a combination of flavonoids and phenolic acids, most of which are weak in nature, and thus act as competent electron donors capable of reacting with $\mathrm{O}^{2-}$ depends entirely on the substitution in the phenolic ring. Our results are in line with the earlier report by Iliass et al., C. sativus petals exhibits less antioxidant activity than stigma but higher than corm with a rise in the concentration of the extract [43]. From the FTIR spectroscopic analysis of C. sativus, the presence of flavonoid, phenolic, esters, aromatic and aliphatic peaks were found in all extracts, whereas in SPE the flavonoid and phenolic presence is more than SPD and SPE [44]. 
Similar results have been documented in earlier studies of antimicrobial effects of different extracts/fraction of $C$. sativus $[26,45,46]$. Petal extracts were found to be more effective at the lowest concentration against pathogenic bacterial strains. Both P. aeruginosa and S. aureus have been inhibited at the lowest inhibitory concentration of $15.63 \mu \mathrm{g} / \mathrm{mL}$. Nevertheless, the extracts of petals were not very effective in inhibiting the growth of E. coli and C. albicans at a lower concentration. This variance in antimicrobial activity of extracts of saffron petals between the studies may possibly be due to the variation in phenolic composition and concentrations in the extracts used $[26,47]$. The results of the study provide evidence of $C$. sativus petals may be a possible source of potential antimicrobial agents [48]. Our results are similar to the earlier study, in which authors noticed a rise in antimicrobial activity of C. sativus extracts with increase in concentrations [49]. The results also revealed that there is very week antimicrobial activity against low polar solvents. In other study, the high polar solvents like alcohol showed significant antimicrobial effects against different bacteria and fungi [50]. Our results are consistent with the previous study conducted by Gandomi et al. which indicated that aqueous, ethanolic and methanolic extracts of saffron petal had increased antimicrobial activity against $S$. aureus in comparison to E. coli. The higher sensitivity for S. Aureus may be due to the arrangement of the cell wall and the outer membrane [51]. The antimicrobial effects of some of the active ingredients of $C$. sativus, such as quercetin, rutin and morin have been reported [52]. Previously also we had performed the analysis of saffron petals by using LC-ESI-Q-TOFMS technique and results confirm the presence of various flavonoids like quercetin, rutin, fisetin and morin [47].

$\alpha$-glucosidase is a crucial carbohydrate digestion enzyme found in the brush-border interface membrane of intestinal cells that decreases postprandial glucose by reducing glucose uptake, which is also a form of treatment and maintenance of diabetes. Glucosidase inhibitors inhibit the activity of $\alpha$-glucosidase enzymes throughout the small intestine, that restrict the translation of carbohydrate for gastrointestinal absorption. Several natural compounds, particularly polyphenols, have been published to have $\alpha$-glucosidase inhibitory activity. SPE had the highest flavonoid and phenolic content followed by SPD and SPH was determined by the Folin-Ciocalteau method. Polyphenolic derivatives found in plant extracts of flavonoids, terpenes have been shown to suppress most of the enzyme $\alpha$-glucosidase, this is thought to be due to the structural similarity between these compounds and the bonds found in natural substrates [53,54].

Research from around the world have shown that polyphenols contained in medicinal plants suppress cell growth and induce apoptosis, thus slowing the growth of numerous cancer cells [55]. Few cell line studies have proven the anti-cancer capabilities of $C$. sativus petals. Safran and crocetin have been reported to induce apoptosis in human breast cancer cells through p53-mediated stimulation of apoptosis [56]. Cell viability tests was performed on the MDA-MB-231 cancer cell lines to determine the relative toxicity of the extracts [57]. Our results are in line with the previous study and found SPE toxicity was to be active and higher against MDA-MB-231, with cell viability declining with steadily increasing concentration.

\section{Conclusions}

The findings of the current investigation concluded significant differences in in vitro antioxidant, antimicrobial, antidiabetic and cytotoxic effects of various solvent extracts of $C$. sativus petals. More research should be conducted to identify new compounds and ascertain which are responsible for these biological activates and to study their impact in animal models.

Author Contributions: Conceptualization, A.F.W. and M.U.R.; data curation, A.F.W., M.U.R.; formal analysis, H.A.A.A., H.K.H., B.K.H., G.A.M.; funding acquisition, A.F.W. and P.A.; investigation, A.F.W., M.U.R. and U.Z.; methodology, A.F.W., G.A.M.; project administration, A.F.W., M.U.R. and P.A.; resources, software, M.U.R., U.Z.; supervision, M.U.R. and A.F.W.; validation, A.F.W., P.A.; writing—original draft, A.F.W., M.U.R.; writing一review and editing, M.U.R. All authors have read and agreed to the published version of the manuscript.

Funding: RSP-2019/116 and RAKMHSU-REC-064-2018-UG-P. 
Acknowledgments: The authors would like to present their gratitude to RAKMHSU for support on this research project RAKMHSU-REC-064-2018-UG-P. The authors would like to extend their sincere appreciation to the Researchers Supporting Project Number (RSP-2019/116), King Saud University, Riyadh, Saudi Arabia.

Conflicts of Interest: The authors declare no conflict of interest.

$\begin{array}{ll}\text { Abbreviations } & \\ \text { SPH } & \text { Saffron petals hexane extract } \\ \text { SPD } & \text { Saffron petals dichloromethane extract } \\ \text { SPE } & \text { Saffron petals ethanol extract } \\ \text { TPC } & \text { phenolic content } \\ \text { TFC } & \text { Total flavonoid content } \\ \text { GAE/g } & \text { Gallic acid equivalent per gram } \\ \text { QE/g } & \text { Quercetin equivalent per gram } \\ \text { DPPH } & \text { 2, 2-diphenyl-1-picry1hydrazy1 } \\ \text { ABTS } & \text { (2,2'-azino-bis(3-ethylbenzothiazoline-6-sulfonic acid) } \\ \text { BHA } & \text { Butylated hydroxyanisole. } \\ \text { R2 } & \text { Regression } \\ \text { IC50 } & \text { Half maximal inhibitory concentration } \\ \text { FTIR } & \text { Fourier transform infrared spectrometry } \\ \text { ATCC } & \text { American Type Culture Collection } \\ \text { NCPF } & \text { National Collection of Pathogenic Fungi } \\ \text { NCCLS } & \text { National Committee for Clinical Laboratory Standards } \\ \text { DMSO } & \text { Dimethyl sulfoxide } \\ \mu \text { Mg/mL } & \text { microgram/mL } \\ { }^{\circ} \text { C } & \text { Celsius } \\ \text { MTT } & \text { 3-(4,5-dimethylthiazol-2-yl)-2,5-diphenyltetrazolium bromide } \\ \text { MDA-MB-231 } & \text { Triple negative breast cancer cell line } \\ \text { LC-ESI-Q-TOFMS } & \text { Liquid chromatography coupled with electrospray ionization-quadrupole-time of } \\ & \text { flight-mass spectrometry } \\ & \end{array}$

\section{References}

1. World Health Organization (WHO). List of Blueprint Priority Diseases. 2018. Available online: www.who. int/blueprint/priority-diseases/en/ (accessed on 7 February 2019).

2. Cosgrove, S.E.; Qi, Y.; Kaye, K.S.; Harbarth, S.; Karchmer, A.W.; Carmeli, Y. The impact of methicillin resistance in Staphylococcus aureus bacteremia on patient outcomes: Mortality, length of stay, and hospital charges Infect. Control. Hosp. Epidemiol. 2005, 26, 166-174. [CrossRef]

3. Ventola, C.L. The antibiotic resistance crisis: Part 1: Causes and threats. P \& T Peer-Rev. J. Formul. Manag. 2015, 40, 277-283.

4. Jesus, G.D.; Emmy, T.; Julio, C.E.A.; Gabriel, L.M.; Paul, C.; Luc, P. Antimicrobial activity of leaf extracts and isolated constituents of Croton linearis. J. Ethnopharmacol. 2019, 236, 250-257.

5. Aslam, B.; Wang, W.; Arshad, M.I.; Khurshid, M.; Muzammil, S.; Rasool, M.H.; Salamat, M.K.F. Antibiotic resistance: A rundown of a global crisis. Infect. Drug Resist. 2018, 11, 1645-1658. [CrossRef] [PubMed]

6. Rehman, M.U.; Wali, A.F.; Ahmad, A.; Shakeel, S.; Rasool, S.; Ali, R.; Khan, R. Neuroprotective Strategies for Neurological Disorders by Natural Products: An update. Curr. Neuropharmacol. 2018, 17, 247-267. [CrossRef] [PubMed]

7. Mehlhorn, H. The Continued Rise in the Magnitude of Bacterial Resistance to Traditional Antibiotics is a Concern of Global Significance, 6th ed.; Encyclopedic Reference of Parasitology; Springer Press: Berlin, Germany, 2014.

8. Verica, A.; Sabo, P.K. Antimicrobial activity of Eucalyptus camaldulensis Dehn. plant extracts and essential oils: A review. Ind. Crops Prod. 2019, 32, 413-429.

9. Djeridane, A.; Yousfi, M.; Nadjemi, B.; Boutassouna, D.; Stocker, P.; Vidal, N. Antioxidant activity of some Algerian medicinal plants extracts containing phenolic compounds. Food Chem. 2006, 97, 654-660. [CrossRef]

10. Othman, L.; Sleiman, A.; Abdel-Massih, R.M. Antimicrobial Activity of Polyphenols and Alkaloids in Middle Eastern Plants. Front. Microbiol. 2019, 10, 911. [CrossRef] [PubMed] 
11. Dorman, H.; Deans, S. Antimicrobial agents from plants: Antibacterial activity of plant volatile oils. J. Appl. Microbiol. 2008, 88, 308-316. [CrossRef]

12. Eruygur, N.; Koçyigit, U.M.; Taslimi, P.; Atas, M.; Tekinf, M.; Gulçin, I. Screening the in vitro antioxidant, antimicrobial, anticholinesterase, antidiabetic activities of endemic Achillea cucullata (Asteraceae) ethanol extract. S. Afr. J. Bot. 2019, 120, 141-145. [CrossRef]

13. Lim, T.K. Edible Medicinal and Non Medicinal Plants. Flowers Crocus sativus; Springer: Amsterdam, The Netherlands; New York, NY, USA; London, UK, 2014; Volume 8.

14. Melnyk, J.P.; Wang, S.; Marcone, M.F. Chemical and biological properties of the world's most expensive spice: Saffron. Food Res. Int. 2010, 43, 1981-1989. [CrossRef]

15. Liakopoulou-Kyriakides, M.; Kyriakidis, D. Crocus sativus biological active constituents. Stud. Nat. Prod. Chem. 2002, 16, 293-312.

16. Carmona, M.; Zalacain, A.; Salinas, M.R.; Alonso, G.L. A new approach to saffron aroma. CRC Crit. Rev. Food Sci. Nutr. 2007, 47, 145-159. [CrossRef] [PubMed]

17. Bagri, J.; Yadav, A.; Anwar, K.; Dkhar, J.; Singla-Pareek, S.L.; Pareek, A. Metabolic shift in sugars and amino acids regulates sprouting in Saffron corm. Sci. Rep. 2017, 7, 11904-11914. [CrossRef]

18. Mokhtari-Zaer, A.; Khazdair, M.R.; Boskabady, M.H. Smooth muscle relaxant activity of Crocus sativus (saffron) and its constituents: Possible mechanisms. Avicenna J. Phytomed. 2015, 5, 365-375.

19. Rahaie, S.; Gharibzahedi, S.M.T.; Razavi, S.H.; Jafari, S.M. Recent developments on new formulations based on nutrient-dense ingredients for the production of healthy-functional bread: A review. J. Food Sci. Technol. 2012, 51, 2896-2906. [CrossRef]

20. Mollaei, H.; Safaralizadeh, R.; Babaei, E.; Abedini, M.R.; Hoshyar, R. The anti-proliferative and apoptotic effects of crocin on chemosensitive and chemoresistant cervical cancer cells. Biomed. Pharmacother. 2017, 94, 307-316. [CrossRef]

21. Abdel-Rahman, R.F.; El Awdan, S.A.; Hegazy, R.R.; Mansour, D.F.; Ogaly, H.A.; Abdelbaset, M. Neuroprotective effect of Crocus sativus against cerebral ischemia in rats. Metab. Brain Dis. 2019, 1-13. [CrossRef]

22. Samarghandian, S.; Azimi-Nezhad, M.; Samini, F. Ameliorative effect of saffron aqueous extract on hyperglycemia, hyperlipidemia, and oxidative stress on diabetic encephalopathy in streptozotocin induced experimental diabetes mellitus. BioMed Res. Int. 2014, 1-12. [CrossRef]

23. Hosseinzadeh, H.; Ziaee, T.; Sadeghi, A. The effect of saffron, Crocus sativus stigma, extract and its constituents, safranal and crocin on sexual behaviors in normal male rats. Phytomedicine 2008, 15, 491-495. [CrossRef]

24. Asdaq, S.M.B.; Inamdar, M.N. Potential of Crocus sativus (saffron) and its constituent, crocin, as hypolipidemic and antioxidant in rats. Appl. Biochem. Biotechnol. 2010, 162, 358-372. [CrossRef] [PubMed]

25. Ding, H.; Zhong, Y.; Qi, Y.; Cheng, W.; Li, S.; Yan, X. Wang Anti-arthritic effects of crocin in interleukin-1 $\beta$-treated articular chondrocytes and cartilage in a rabbit osteoarthritic model. Inflamm. Res. 2013, 62, 17-25. [CrossRef] [PubMed]

26. Javid, A.P.; Azra, N.K.; Rehana, H.; Zafar, A.R.; Raies, A.Q. Antibacterial and antioxidant activity of methanol extracts of Crocus sativus L. c.v. Kashmirianus. Front. Life Sci. 2014, 8, 40-46.

27. Chang, C.C.; Yang, M.H.; Wen, H.M.; Chern, J.C. Estimation of total flavonoids content in propolis by two complementary colorimetric methods. J. Food Drug Anal. 2002, 10, 178-182.

28. Kaur, C.; Dalamu, M.; Singh, S.; Walia, S.; Joshi, A.D. Variations in phenolics and antioxidants in Indian onions (Allium cepa L.) Genotype selection for breeding. Nutr. Food Sci. 2004, 40, 6-19.

29. Wang, D.M.; Zhang, Y.J.; Wang, S.S.; Li, D.W. Antioxidant and antifungal activities of extracts and fractions from Anemone taipaiensis, China. Allelopath. J. 2013, 32, 67-68.

30. Tan, X.Q.; Guo, L.J.; Chen, H.S.; Wu, L.S.; Kong, F.F. Study on the flavonoids constituents of Trachelospermum jasminoides. J. Chin. Med. Mater. 2010, 33, 58-60.

31. Rahman, A.A.; Samoylenko, V.; Jain, S.K.; Tekwani, B.L.; Khan, S.I.; Jacob, M.R.; Muhammad, I. Antiparasitic and antimicrobial isoflavanquinones from Abrus schimperi. Nat. Prod. Commun. 2012,6,1645-1650. [CrossRef]

32. Tao, Y.; Zhang, Y.; Cheng, Y.; Wang, Y. Rapid screening and identification of $\alpha$ - glucosidase inhibitors from mulberry leaves using enzyme-immobilizedmagnetic beads coupled with HPLC/MS and NMR. BioMed Chromatogr. 2013, 27, 148-155. [CrossRef] 
33. Yusra, A.; Ali, E.; Synan, A.Q.; Samir, A.; Mohammad, K.; Ghenima, A.; Soleiman, H.; Rabah, I. Mitotic Arrest and Apoptosis in Breast Cancer Cells Induced by Origanum majorana Extract: Upregulation of TNF- $\alpha$ and Downregulation of Survivin and Mutant p53. PLoS ONE 2013, 8, e56649.

34. Mzabri, I.; Addi, M.; Berrichi, A. Traditional and Modern Uses of Saffron (Crocus Sativus). Cosmetics 2019, 6, 63. [CrossRef]

35. Somayeh, R.; Sohrab, M.; Maryam, H.; Seyed, A.S. Evaluation of antioxidant activities of bioactive compounds and various extracts obtained from saffron (Crocus sativus L.): A review. J. Food Sci. Technol. 2015, 52, 1881-1888.

36. Kumar, S.; Pandey, A.K. Chemistry and biological activities of flavonoids: An overview. Sci. World J. 2013, 2013, 162750. [CrossRef] [PubMed]

37. Karimi, E.; Oskoueian, E.; Hendra, R.; Jaafar, H.Z. Evaluation of Crocus sativus L. stigma phenolic and flavonoid compounds and its antioxidant activity. Molecules 2010, 6, 6244-6256. [CrossRef] [PubMed]

38. Duangjai, T.; Areeya, T.; Apinan, P.; Aujana, Y. Flavonoids and Other Phenolic Compounds from Medicinal Plants for Pharmaceutical and Medical Aspects: An Overview. Medicines 2018, 5, 93. [CrossRef]

39. Forni, C.; Facchiano, F.; Bartoli, M. Beneficial Role of Phytochemicals on Oxidative Stress and Age-Related Diseases. BioMed Res. Int. 2019, 7, 8748253. [CrossRef]

40. Nowacka, N.; Nowak, R.; Drozd, M.; Olech, M.; Los, R.; Malm, A. Antibacterial, antiradical potential and phenolic compounds of thirty-one polish mushrooms. PLoS ONE 2015, 10, 0140355. [CrossRef]

41. Ferreira, I.C.F.R.; Baptista, P.; Vilas-Boas, M.; Barros, L. Free-radical scavenging capacity and reducing power of wild edible mushrooms from northeast Portugal: Individual cap and stipe activity. Food Chem. 2007, 100, 511-1516. [CrossRef]

42. Mathew, S.; Abraham, T.E.; Zakaria, Z.A. Reactivity of phenolic compounds towards free radicals under in vitro conditions. J. Food Sci. Technol. 2015, 52, 5790-5798. [CrossRef]

43. Baba, S.A.; Malik, A.H.; Wani, Z.A.; Mohiuddin, T.; Shah, Z.; Abbas, N.; Ashraf, N. Phytochemical analysis and antioxidant activity of different tissue types of Crocus sativus and oxidative stress alleviating potential of saffron extract in plants, bacteria, and yeast. S. Afr. J. Bot. 2015, 99, 80-87. [CrossRef]

44. Lahmass, I.; Ouahhoud, S.; Elmansuri, M.; Sabouni, A.; Elyoubi, M.; Benabbas, R.; Saalaoui, E. Determination of Antioxidant Properties of Six By-Products of Crocus sativus L. (Saffron) Plant Products. Waste Biomass Valoriz. 2018, 8, 1349-1357. [CrossRef]

45. Fei, Y.L.; Thet, T.H.; Gabriel, A.A. ATR-FTIR and spectrometric methods for the assay of Crocin in commercial saffron spices (Crocus savitus L.). Int. J. Food Prop. 2015, 18, 1773-1783.

46. Maryam, A.; Afshin, R.; Seyed, S.S.; Hamdollah, M. The effects of aqueous and alcoholic saffron (crocus sativus) tepal extracts on quality and shelflife of pacific white shrimp (litopeneous vannamei) during iced storage. J. Food Qual. 2016, 39, 732-742.

47. Cenci-Goga, B.; Torricelli, R.; Hosseinzadeh, G.Y. In vitro bactericidal activities of various extracts of saffron (Crocus sativus L.) stigmas from Torbat-e Heydarieh, Gonabad and Khorasan, Iran. Microbiol. Res. $2018,9$. [CrossRef]

48. Wali, A.F.; Pillai, J.R.; Al Dhaheri, Y.; Rehman, M.U.; Shoaib, A.; Sarheed, O.; Ahmad, P. Crocus sativus L. Extract Containing Polyphenols Modulates Oxidative Stress and Inflammatory Response against Anti-Tuberculosis Drugs-Induced Liver Injury. Plants 2020, 9, 167. [CrossRef] [PubMed]

49. Syed, M.; Sajad, A.R.; Khaliquz, Z.K. In vitro bactericidal and fungicidal activities of various extracts of saffron (Crocus sativus L.) stigmas from Jammu \& Kashmir, India. Cogent. Food Agric. 2016, 2, 1158999.

50. Eleni, K.; Dimitra, D.; Spiros, P.; Konstantina, A.; Eleftherios, H.D.; Moschos, G.P. Crocus sativus L. tepals: The natural source of antioxidant and antimicrobial factors. J. Appl. Res. Med. Aromat. Plants 2017, 4, 66-74.

51. Carmona, M.; Zalacain, A.; Alonso, G.L. The Chemical Composition of Saffron: Colour, Taste and Aroma, 1st ed.; Bomarzo: Albacet, Spain, 2006.

52. Gandomi, H.; Misaghi, A.; Abbaszadeh, S.; Azami, L.; Shariatifar, N.; Tayyar, N. Antibacterial effect of aqueous and alcoholic extracts from petal of saffron (Crocus sativus) on some foodborne bacterial pathogens. J. Med. Plants 2012, 11, 189-196.

53. Amin, M.U.; Khurram, M.; Khattak, B.; Khan, J. Antibiotic additive and synergistic action of rutin, morin and quercetin against methicillin resistant Staphylococcus aureus. BMC Complement. Altern. Med. 2015, 15, 59. [CrossRef] 
54. Chukwujekwu, J.C.; Amoo, S.O.; de Kock, C.A.; Smith, P.J.; Van Staden, J. Antiplasmodial, acetylcholinesterase and alpha-glucosidase inhibitory and cytotoxicity properties of Buddleja saligna. S. Afr. J. Bot. 2014, 94, 6-8. [CrossRef]

55. Kondhare, D.; Lade, H. Phytochemical profile, aldose reductase inhibitory, and antioxidant activities of indian traditional medicinal Coccinia grandis (L.) fruit extract. 3 Biotech. 2017, 7, 378. [CrossRef] [PubMed]

56. Arul, D.; Subramanian, P. Inhibitory effect of naringenin (citrus flavonone) on N-nitrosodiethylamine induced hepatocarcinogenesis in rats. Biochem. Biophys. Res. Commun. 2013, 434, 203-209. [CrossRef] [PubMed]

57. Mousavi, S.H.; Tavakkol-Afshari, J.; Brook, A.; Jafari-Anarkooli, I. Role of caspases and Bax protein in saffron-induced apoptosis in MCF-7 cells. Food Chem. Toxicol. 2009, 47, 1909-1913. [CrossRef] [PubMed]

C 2020 by the authors. Licensee MDPI, Basel, Switzerland. This article is an open access article distributed under the terms and conditions of the Creative Commons Attribution (CC BY) license (http://creativecommons.org/licenses/by/4.0/). 